In seismology, rocks forming the solid crust of the earth are generally regarded as isotropic or quasi-isotropic ${ }^{2}$. Richards ${ }^{3}$, who studied the elastic properties of limestones, however, makes a reference to their anisotropic behaviour. The deflnitely anisotropic nature of various rocks with a maximum sound velocity along directions normal to the bedding plane or easy breakage planes brought out in this investigation is noteworthy, and has to be taken into account into geophysical calculations based on seismic methods. That eclogite is and known uniform texture.

The full significance of these results will be discussed elsewhere.

Geophysical Laboratories,

Andhra University,
Guntur, India.

'Bhagavantam and Bhimasenachar, Proc. Ind. Acad. Sci., 20, 298 (1944)

2 Jeffreys, H., "The Earth. Its Origin, History and Physical Constitution" (2nd Ed. Cambridge, 1929), 85-100.

s Richards, T. C., Proc. Phys. Soc., London, 45, 70 (1933).

\section{Origin of the First European Potatoes and their Reaction to Length of Day}

WE are interested to see that Dr. van der Plank $^{1}$ has provided additional evidence for the view that the first European potatoes wer short-day types from the Andes of South America rather than longday adapted potatoes from Chile as the Russians have asserted.

We have mentioned elsewhere ${ }^{2,3}$ that in our view the potato, when it first arrived in Europe, was probably of short-day type, hut that the short-day response became modifled when selection for yield took place with plants grown from true seed. Maturity in the potato appears to be governed by a large number of hereditary character which by breeding can be easily modified either towards long-day or short-day expression. While the varieties first brought to Europe were almost certainly short-day in their reaction, there has undoubtedl been a gradual shift towards long-day types which has been accelerated as the potato crop has spread northwards and become a staple food crop.

Unfortunately, Dr. van der Plank has read into our words an inference not quite intended. Thus he states: ". . the Cambridge school ... agrees with the Russian in assuming that short-day Andean types would have been ill-adapted to European conditions, and postulates that if a short-day reaction existed in the frst European potatoes it was something to be removed as early as possible. This view is unacceptable."

Undoubtedly the trend has been gradually to alter the photoperiodic response from short-day towards long-day, but this has taken time and we have never stated that the short-day response was removed at once. There is no reason why the original short-day forms from the Andes could not maintain themselves under European conditions the Andes could not maintain themselves under European conditions
though giving a reduced yield. This is what happens when the recently though giving a reduced yield. This is what happens when the recently
collected Andean forms are grown under the longer days of Great

Although certain old potato varieties do undoubtedly tend towards a short-day response this is by no means true of all of them. For example, the very old variety Edzell Blue is classed as an early second early and must be comparatively long-day in its photoperiodic re early and must be comparatively long-day in its photoperiodic re
action. Similarly the old varieties Bloomers, Flounders, Fortyfold and London Blue, which were all probably growing at or before the time of the potato famine (1845-46), are classed as early and early maincrop varieties and are therefore quite definitely not extreme short-day types. We can say, therefore, that even as early as $1830-50$ short-day types. We can say, therefore, that even as early as $1830-50$ many potato varieties, though by no means all, were tending towards a defnite long-day response. Even the latest maturing old domestic varieties such as Gregor Cups, Lumpers, Red Cups, Rocks, Yam, etc., are not so late in maturing as varieties of Solanum andigenum,

comparative tests (unpublished) carried out by us have shown.
It therefore seems quite clear that even at the beginning of the nineteenth century the European potatoes had passed some distance nineteenth century the European potatoes had passed some distance on the way from the extreme short-day response of their south American progenitors towards the extreme long-day response of our
present-day first early varieties, but the short-day character still exists in European varieties and can be recovered by breeding.

Dr. van der Plank's discovery of the Basutoland types of potato taken from Europe in the 1830 's is of great interest and importance, since they would seem to be relatively unmodifled relicts of the potato varieties of that time. We doubt, however, whether their photoperiodic response is so extremely short-day as the majority of varieties of S. andigenum, though this is a point that could be easily checked by experiment.

With the last paragraph of Dr. van der Plank's communication, on the nomenclature of $S$, tuberosum and $S$. andigenum, we are in the main in agreement. The position has already been stated by one of us (J. G. H. $)^{2}$, and further data are in the course of being compiled on the advisability of retaining the name $S$. tuberosum for all the cultivated tetraploid potatoes. This, involving the examination of type herbarium specimens and many rare documents, is a work of some length which has not yet been completed. It involves the establishment of the botanical type for $S$. tuberosum, the definition of its boundaries, and the relation of the indigenous Andean and Chilean potatoes to it.

Imperial Bureau of Plant Breeding and Genetics, J. G. HAWKES School of Agriculture, Cambridge.

1 Nature, 157, 503 (1946).

2 Drịver, C. M., and Hawkes, J. G., Bull. Imp. Bur. Plant Breed. and Genet., pp. 36 (1943)

"Hawkes, J. G., Bull. Imp. Bur. Plant Breed. and Genet., pp. 142 (1944).
Trial of an Oral Vaccine against Bacterial Infection Accompanying the Common Cold

THE signiflcance of the common cold 2 industry and the incapacity The significance of the common cold 3 industry and the incapacity and loss of time that result require no 1 nphasis. It is estimated that
millions of man-days of work are lost e ch year as the result of upper millions of man-days of work are lost e ch year as the result of upper
respiratory tract infections. It seems kely that the filterable virus is the primary causative agent, and lat secondary symptoms are is the primary causative agent, and lat secondary symptoms are ine to bacterial infection. It was felt, as a result of reports appearing in the American medical press and in view of the shortage of labour in 1944-45, that it would be useful to attempt to

It was decided to carry out a large-scale experiment in the factories under my care and estimate the value of such a vaccine. The oral vaccine, if it worked, would be the only practical method of administration in a large group of workers. In collaboration with a wellknown firm of manufact
contained the following:

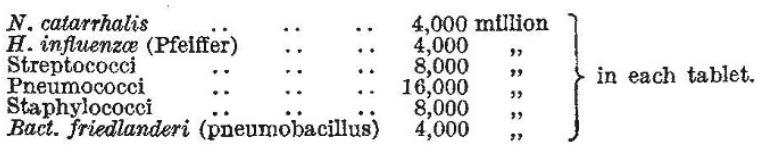

A tablet of the same size, colour and shape containing no vaccine but a carbohydrate compound was also prepared for administration to controls. A tablet was given daily for at least flve days, and this was then repeated after a fourteen-day interval. An evaluation was attempted to show if the oral vaccine does convey an immunity, and, if so, what was its duration. The course was commenced on October 16 , 1944 , and results were tabulated for 34 . weeks. 1,068 people were
given the vaccine tablets and 985 were given the control tablets. The results from the point of view of conveying any immunity were disappointing. The results for the period showed practically the same incidence of colds in each group : 1,476 with the vaccine tablet as compared with 1,455 with the control tablet. The weekly incidence was practically the same for both groups.

These results are not in line with the published figures of the American observers, who claim good results with similar experiments but on a smaller scale; although it must be stated that the American Medical Association is not satisfled that oral vaccines are of much value.

A detailed report will be published elsewhere.

A. C. Cossor, Itd.,

L. B. Botrine.

Highbury Grove,

Feb. 25 .

(Medical Officer.)

REFERENCES,

Rockwell, et al., J. Lab. Clin. Med., 22, 912 (1937)

Joiner, H., J. Med. Assoc. Georgia, 38, 332
Stafford, C. I., Journal-Lancet, 60, $319(1940)$.

\section{Lantern Slides of Diagrams, Formulæ, etc.}

DIAGRAMs, line drawings, tables, formulæ, etc., are best written or drawn directly on non-photographic type lantern slides. These have been variously prepared by dissolving Canada balsam in benzole ${ }^{2}$ toluene $e^{2}$ and other high boiling-point solvents. In all cases artiflcial heat is needed for quick drying, and a drop of the coating material
(wastage) is formed in the bottom corner of the slides when stacked

I have avoided these difficulties by using low boiling-point solvents the most effective being dichloroethylene. A preparation of a 1:8 to $1: 4$ parts by weight of a solution of Canada balsam in dichloroethylene results in a perfectly smooth coating which takes equally well Indian ink, paint or dye, and may be written or drawn upon with any type of instrument. The solution is poured on to the centre of the glass slide, and it spreads almost immediately over the entire area of the slide. At ordinary room temperature the coating dries practically instantaneously due to the low boiling-point $\left(55^{\circ} \mathrm{C}.\right)$ of the solvent employed.

\section{Mary Vale Road \\ Bournville, \\ Dec. 29.}

1 Robinson, H. A., Brit. J. Photography, 84, 680 (1937).

Barber, D. R., J. Sci. Instr., 15, 5, 174 (1938).

\section{"Annual Review of Biochemistry"}

in his admirable review of volume 14 of the "Annual Review of Biochemistry"' , Prof. G. F. Marrian takes marked exception to the
omission of authors' names in the text and the use of bibliographic omigsion of authors' names in the text and the use of bibliographic numbers only, and uses an article by Dr. Barker, Dr. Jordan and myself as the peg on which full : but we were asked by the editors of share his objections to the full ; but we were asked by the editors of the "Annual Review of Biochemistry" to adopt this procedure and we therefore complied, although at some trouble to ourselves. Other authors may, or may not, have responded to this request, if it was
made to them.

${ }^{1}$ Nature, 157, 460 (1946).
J. Masson Gullain. 